\title{
The (de)construction of culture in interpreter-mediated medical discourse
}

\section{Tatjana R. Felberg \& Hanne Skaaden}

Oslo and Akershus University College of Applied Sciences

In Norway, perceived communication problems in medical encounters with minority patients are often ascribed to 'culture' by the professional in charge of the institutional dialogue. Even in literature on medical encounters involving language barriers and interpreting, culture is used as an explanatory tool for observed complications, and an expansion of the interpreter role is suggested as the remedy. Comparing statements about the concept 'culture' made by medical professionals against a backdrop of Norwegian legislative texts on the role of the medical professional and interpreter, this article deconstructs culture as an explanatory tool. It is suggested that the source of the perceived problems of communication may lie at general levels of human interaction, e.g. concentration or language proficiency, rather than culture. We argue that the use of the concept of culture may lead to 'othering' of minority patients, may conceal rather than reveal communication problems, and may confuse the intersection between interpreters' and medical professionals' areas of expertise. Ultimately, not only minority patients' health but also medical personnel's professional integrity may be threatened.

\section{Introduction}

(1) I interpreted at a hospital. It was psychiatric therapy. After the session the therapist asked me about the patient: "Do you think he's mad?" What am I supposed to answer? I'm no psychiatrist. (Skaaden 2010: 470)

This quote from a Somali interpreting student serves to illustrate the barrier of communication facing medical personnel that treat minority patients. The language barrier deprives medical professionals of control over the institutional dialogue, i.e., dialogues where "one person who represents an institution encounters another person, seeking its services" (Agar, 1985, p. 147). Such dialogue (e.g., the doctor-patient conversation) serves as a basic tool in medical personnel's practice (Woloshin et al., 1995, p. 724). Medical professionals who lack a common language with the patient depend on interpreters' services in order to perform their tasks and maintain professional integrity. In the case of a language barrier, interpreting enables professionals or public servants to inform, guide, and hear the parties in the case at hand (Jahr et al., 2005, p. 28). At the same time, research reports (IMDi, 2007; Kale, 2006) indicate that, when confronted with a language barrier, medical professionals often rely on ad-hoc solutions such as the 
patient's relatives, sometimes even children, to overcome communication barriers.

A survey among general practitioners (GPs) in Norway (IMDi, 2007) shows that the majority of Norwegian GPs see the danger of the language barrier in causing an erroneous diagnosis (62\%), resulting in wrong treatment $(60 \%)$, or leaving symptoms undetected (67\%; IMDi, 2007, pp. 45-47). ${ }^{1}$ Interestingly, 79\% of GPs nonetheless "frequently" (38\%) or "sometimes" (41\%) rely on patients' relatives to overcome the language barrier. Nearly a third (29\%) even admit to "sometimes" communicating via minors (IMDi, 2007, p. 38). Similarly, in a survey among healthcare workers in the Oslo region, $85 \%$ admit to frequently or sometimes communicating via patients' relatives (Kale, 2006). This result is surprising because Kale's respondents also label the ability "to act impartially" (98\%) and "to accurately convey the content" $(96 \%)$ to be "an interpreter's most important qualities" (Kale, 2006, p. 26).

Despite research showing that hospitalization of minority patients is reduced by 0.9 nights when the language barrier is bridged by an interpreter (Jacobs et al., 2004), the tendencies reflected above are not limited to Norway. For instance, a survey from the Austrian healthcare scene (Pöchhacker, 1997) shows similar attitudes among medical professionals in Vienna. Studies from Germany (Meyer, 2001) and Italy (Merlini, 2009) illustrate how other medical staff and relatives serve in the interpreter function. The discourse analyzed in these studies reveals that such "interpreters" lack both the bilingual skills and understanding of the interpreter function necessary to perform the challenging task of interpreting. As a result, such "interpreting" frequently serves to complicate communication rather than to reveal misunderstandings in medical encounters (see, for example, Merlini, 2009, pp. 105-106; Meyer, 2001, p. 93).

Complications observed under such conditions are often attributed to cultural differences (e.g., Angelelli, 2004a, p. 99), and the remedy prescribed is expansion of the interpreter's function into that of a cultural broker and contractual mediator or advocate (Galal \& Galal, 1999, p. 15). ${ }^{2}$ Pöchhacker (2004, p. 148) notes that emphasis on "a more broadly construed role for the interpreter" also occurs in domains other than the medical. However, the idea of an expanded role, that emanates from the study of interpreting in the Canadian health-care system, is "to redress power imbalances in cross-cultural clinical encounters". In this article we question whether an interpreter serving as a "cultural mediator" in this broadened sense is a reliable bridge over the troubled waters described above. The aim of the analysis is to shed light on the following research questions: How is 'culture' constructed in the discourse of the medical professionals when referring to perceived difficulties in communication with minority patients? To what extent do the medical professionals' 
constructions agree with Norway's legislation? And how well does culture fare as an explanatory tool?

We argue that the use of the concept culture as an explanatory tool may lead to 'othering', partly due to the complexity of the concept culture as such. The term 'othering' originates from the philosopher Emmanuel Lévinas' discussions on the relation between Self and Other (Finkielkraut, [1984] 1997). Lévinas' phenomenological ethics argue against reducing "your neighbor" into "a categorically abstract otherness"; that is, a stance "that reduces the Jew to Judaism, the Moslem to Islam, the black to Black is beautiful, which, in a general way, says every individual possesses no being but that of the species" (Finkielkraut, 1997, p. xiv-xv). Today the concept of 'othering' is applied to various fields within philosophy, post-colonial studies, anthropology, and psychiatry. Here, we adopt an understanding of the concept as ways in which one group of people (e.g., medical professionals) may exclude another group of people (e.g., minority patients) through constructions of them as being "different":

Othering is part of the process of talking and writing about patients [...] Othering implies difference and division between us and them [...] Othering is essentially about constructing dualisms. (Maccallum, 2002, pp. 87-88)

Culture is a concept often linked to one's opinion of the Other (Finkielkraut, [1984] 1997). The concept of culture is also often linked to that of interpreting, through terminology such as "cultural mediation". Pöchhacker (2008) analyzes the second part of the term "cultural mediation" as applied to the interpreter. His analysis shows how three different dimensions of the term mediation have influenced a conflicting construal of the interpreter function-in terms of cognitive, cultural/linguistic, and contractual facilitation (Pöchhacker, 2008, p. 12). Below we show that the term culture itself adds challenges to the construal of the interpreter as something more than an individual installed with the power of "relaying and coordinating other's talk" (Pöchhacker, 2008, p. 23).

\section{Materials and methods}

The data examined consist of reports on perceived difficulties in communication with minority patients made by medical professionals in the Norwegian public sector. Their statements are gathered through focus groups or one-on-one interviews, where the participants respond to openended questions such as "what are the advantages of communicating via an interpreter?"; "what do you consider the main challenges when communicating via an interpreter?". When necessary the open-ended 
questions were trailed by follow-ups such as "could you please give a concrete example?" (Felberg, 2012; Felberg, Imsen, \& Skaaden, 2011; IMDi, 2007). The data were collected and anonymized in line with Norwegian Social Science Data Services' guidelines. The data were gathered on more occasions. Focus Group A $(n=8)$ was organized while preparing an e-learning program on communication via interpreters for medical professionals (Felberg, Imsen, \& Skaaden, 2011), ${ }^{3}$ Focus Group B $(n=68)$ was organized in the process of developing the course "Communication via Interpreters" and consisted of five meetings with 8-15 participants each (Felberg, 2012). Focus groups A and B were both organized in order to compile feed-back on the participant's experiences and perceived needs when confronted with a language barrier. Finally, we draw on data from twelve in depth interviews with GPs participating in the above-mentioned IMDi (2007) study, conducted in order to supplement the quantitative survey. In the analysis below, excerpts from these occasions are referred to as Focus Groups A, B, and C, respectively. Despite the different contexts in which the data are gathered the participants on all occasions recurrently emphasize 'culture' in their descriptions of communication difficulties. Hence, the excerpts selected are representative of the data as a whole.

Moreover, excerpts from interpreting students' discussions on their experiences from the public sector serve to shed light on how culture is construed in the Norwegian public sector. The chat discussions $(n=380)$ took place as part of a web-based training course for interpreters in the period 2004-2010. The students represent a wide variety of languages and engage in the discussions by responding to a moderator's open-ended questions on perceived challenges in the interpreter function including cultural mediation, the danger of burn-out and threats to the interpreter's own health (see Skaaden \& Wattne, 2009).

Following the constructionist view of society (Potter, 1996), social identities and relations are seen as discursively constructed, and thus flexible and changeable rather than fixed and stable. The world "is constituted in one way or another as people talk it, write it, and argue it" (Potter, 1996, p. 98). In analyzing discourse in which medical personnel describe perceived difficulties in their communication with minority patients, we identified culture as a recurring theme and explanatory tool. In the analysis below we focus on the use of the concept culture as an explanatory tool. First, we survey Norwegian legislation's constructions of institutional discourse, its dialogical perspectives on medical treatment, and the area of responsibility it assigns to the professionals taking part in it, medical personnel and interpreters alike. We then go on to illustrate how medical personnel's reflections signal 'othering', through their use of the concept of culture in order to explain the problems perceived. Finally, we analyze the concept of culture in order to illustrate its shortcomings as an explanatory tool based on models of the interrelationship between culture, 
individual and language within anthropology and linguistics (Langacker, 1994; Piller, 2011; Scollon \& Scollon, 2001; Wikan, 2002). The aim of our discussion is to display the weaknesses in the strategy of solving the perceived communication problems between minority patients and medical professionals by installing the interpreter as a "cultural remedy" to fill a communicative void.

\section{Analysis}

The process of professionalizing the interpreter's function in the public sector is in its early stages. However, in Norway several measures have been taken to enhance the profession's status, including an accreditation exam, university-level training, a National Register of Practicing Interpreters (www.tolkeportalen.no), and measures to raise the consciousness of professionals in need of an interpreter's services in their jobs (Felberg, in press $a, b$; Skaaden, 2007). In Norway, interpreting in healthcare services is considered part of the broader field of interpreting in the public sector, as defined in the above introduction (see Jahr et al., 2005). From the professional's vantage point, the definition above highlights the fact that the professional in charge of the institutional dialogue is the (co)owner of the communication problems caused by a language barrier.

\subsection{Norwegian legislation: delineating areas of responsibility}

According to reports cited in the introduction, $24 \%$ of medical personnel explicitly ascribe ownership of the communication problem to the patient alone (IMDi, 2007, p. 40). The tendency is further implicit in the fact that medical personnel admit to communicating with patients via family members instead of an interpreter as frequently as $79 \%$ and $84 \%$ of the times according to IMDI (2007, p. 38) and Kale (2006, p. 23), respectively. At this point they are out of step with Norwegian legislation, as defined in various documents. The Norwegian Patients' Rights Act (2001) clearly states the patient's right to information and complicity ( $\$ 3.2-3.5)$, along with the medical personnel's obligations to accommodate both. ${ }^{4}$ Moreover, it explicitly states the medical professional's responsibility to adapt information to the ability of the individual patient's "age, maturity, experience, and cultural and linguistic background" and to arrange for it to "be provided in a considerate manner" (\$3.5).

In its commentary, the Patients' Rights Act also identifies interpreting as a way to provide adapted information (Lov om pasientrettighteter, Rundskriv, IS12/2004 p. 28, Sosial- og helsedirektoratet). Medical professionals' need to rely on interpreting was 
recently elaborated on in the guide Veileder om kommunikasjon via tolk for ledere og personell $i$ helse og omsorgstjeneste (Communication via an Interpreter. A Guide for Healthcare Service Directors and Personnel, The Directorate of Health, 2011].

In the Norwegian public sector, the interpreter's area of responsibility is stated in Retningslinjer for god tolkeskikk (Guidelines for Best Practice in Interpreting). These guidelines were implemented when the accreditation for interpreters was established in 1997 (KAD, 1997). Built around the core principles of fidelity and impartiality, the guidelines delineate the interpreter's area of responsibility in line with the view of the interpreter as someone "relaying and coordinating other's talk" (see Pöchhacker, 2008, p. 23). In fact, the guidelines (\$7) explicitly state that the interpreter is not to serve as an "informant" on cultural issues. In their commentary, the guidelines emphasize that such a strategy may harm the interpreter's integrity. Moreover, the commentary emphasizes the interpreter's shortcomings in the function of a "culture broker," much in line with the point made by Wadensjö (1998, pp. 51-52) that an interpreter focusing on "how things usually are" may easily "block his attentiveness to each situation's uniqueness."

In sum, Norwegian legislation clearly states that the medical personnel's area of responsibility includes communication with the patients they serve. Moreover, the Norwegian guidelines emphasize the importance of the interpreter's impartial position in institutional discourse in order to maintain the function's integrity and the trust of both interlocutors at all points.

\subsection{Medical professionals' constructions of the Other}

How do the medical professionals in our focus groups construct their area of responsibility and the problems perceived in communication with patients from minority populations? The medical personnel construct the communication problem in a different manner than the legislative texts: in line with the reports quoted above they often ascribe the ownership of the communication problem to the patient. We also found that the concept of 'culture' was a frequently employed "explanatory tool" for the difficulties perceived. In our data the medical professionals' talk about minority patients basically occurs along two lines, as exemplified in (2a) and (2b), respectively. That is to say, "their culture" is seen as preventing both the use of interpreters and participation in the Norwegian society:

(2) a. Their culture does not allow them to use interpreters. (Focus Group B)

b. Their culture does not allow them to participate in the Norwegian society. (Focus Group B) 
When asked to elaborate on the statement in example (2a), one participant shared an experience that he presented as a common dilemma for medical professionals:

(3) A patient's husband insists on interpreting for his own wife, the [patient's] rationale being that according to his culture no other man, including a male interpreter, can come close to his wife. Although I was not at ease with the decision, I accepted his rationale and allowed the husband to function as an interpreter. (Focus Group B)

Accordingly, the difficulties perceived in communication are ascribed to the minority patient's otherness or being different from Us due to his culture-in (3) exemplified through the medical personnel's construction of the Other's gender roles. Hence, a construction in which the individual is disregarded. The construction of difference may be further re-enacted with the notion that only Others are carriers of culture, whereas We by default are neutral or normal. The medical personnel do not refer to themselves as carriers of culture, be it professional, religious or national. It should be stressed that this picture from the focus group sessions is not totally black and white. Some participants see the complexity of the situation as also depending on the particular features of their own medical culture:

(4) At the maternity ward a problem may arise when the father insists on serving as the interpreter, and we need to talk to the mother alone. It is difficult to reject him, you know, because it's also our strategy to involve the father actively in nurturing the baby from day one. (Focus Group A)

Despite reflections like those of the midwife in example (4), the tendency to ascribe the source of the problem to the minority speaker's culture being different is predominant. Moreover, there is a tendency that diverse problems of communication are classified as part of "their culture":

(5) When we [i.e. the GPs] start to talk about edible fat and carbohydrates and such things, they don't know anything about it. When we then speak about the diet, it's very difficult ... they don't understand the concepts; when we say eat less fat, they ask "what's fat?" They don't understand the concept of what carbohydrates are, what proteins are. Then it's difficult to help ... many of them come here without knowing how to read or write, they lack basic knowledge ... (Focus Group C)

The GP's description of the communication problem in example (5) symbolizes a tendency to designate its source to a void in "their" [i.e., the minority patients'] culture. However, concepts such as carbohydrates and 
proteins are technical terms of the "medical culture," and even patients from the majority population may have problems with grasping their full meaning.

A recurring example linked to the interactional aspect of information mediation pertains to minority patients' ability to grasp "medical terminology":

(6) Minority patients may answer yes, or nod, when asked whether they've understood the instructions or terminology, although you can literally "sense" that the patient didn't understand. (Focus Group A)

In the Norwegian context, this "nodding problem" was cited by public servants to illustrate "cultural differences" (Dahle \& Ryssevik, 2011). Minority patients that "fake" understanding seem to be a perceived problem among medical personnel outside Norway as well, since the problem is referred to by several authors under the rubric of culture (Dysart-Gale, 2005; Rudvin, 2006). The fact that the "nodding problem" is international makes it legitimate to question whether the problem actually pertains to culture. The source of the problem may simply lie at the level of cognition; that is, the patient is trying to cope with a complex situation and insufficient linguistic skills. Anyone that has acquired a new language in another country can recognize that moment of information overflow when the receptive capacity limits itself to keeping the relation going by nodding and supplying the stream of discourse with the odd smile and $\mathrm{mhm}$.

When prompted to explain what they do in situations when a patient seems to "fake" understanding, the respondents admitted that they would often accept the patient's "yes" but perceive of the situation as less than satisfactory. Interestingly, some respondents (Focus Group B) reported that they would ask the interpreter if the patient really understood what had been said. This solution seems to coincide with a tendency to perceive of the interpreter as part of the Other. The observation made by the interpreting student in the chat discussion in example (7) illustrates this tendency:

(7) $\quad(m=\text { male, Sora=Sorani, followed by time of posting })^{5}$

Moderator-18:24 > If one of the speakers signals his or her distrust towards the interpreter; e.g. because of ethnicity. How may this drain the interpreter's energy? Any examples?

mSora1-18:25 > one thing I have noticed is that some people [i.e., professionals, e.g., medical personnel] regard the interpreter as the client's representative. They even use the word dere [i.e., the Norwegian 'you (plural) pronoun' to refer to the interpreter and client/patient collectively]. 
The assignment of the interpreter to the position of the Other is manifested here by the fact that some professionals even address the minority language-speaking party and the interpreter with the joint plural form of the pronoun 'you' (Norwegian dere).

In sum, the patients' Otherness emanating from their culture is frequently foregrounded in identifying the source of a perceived communication problem. This finding is in line with the tendency in Kale's study, in which $55 \%$ of the respondents wanted the interpreter's task to be extended to cultural mediation (Kale, 2006, pp. 31-32; see Kale, Ahlberg, \& Duckert, 2010, p. 820). Moreover, medical personnel frequently expressed the need to learn more about foreign cultures in order to regain control (Kale, 2006, pp. 31-32; see Kale, Ahlberg, \& Duckert, 2010, p. 820). The constructions above predominantly represent institutional discourse as a meeting between a Norwegian individual (the Self) and a foreign culture (the Other). This construction of the "problem source" consequently influences how medical personnel perceive the interpreter's role. Construction in this sense pertains to Potter's view of reiterating a certain image by recurrently naming, talking, and writing about a certain phenomenon in a certain way, as defined in the Introduction.

In the below discussion we see 'othering' as a consequence of a particular use of the concept 'culture'. Within this construction, the interpreter, being assigned membership in the Other culture, is assumed to be an excellent source of information about the Other. (In fact, this perspective is so deeply rooted that the possibility of the interpreter being of Norwegian ethnicity is never mentioned.) Accordingly, the solution to the problem of communication is to place the interpreter in the role of a cultural oracle. In the next subsection we analyze the concept 'culture' with the aim to explore where this strategy may lead. Hence, we first outline difficulties with defining the concept. Then, we go on to identify problems with using 'culture' in an explanatory function and illustrate that these are caused by culture's intersection with language, individual and group.

\section{Discussion}

Culture is recurrently used as a self-explanatory concept in our data. Moreover, in literature on linguistics and interpreting, language and culture are often mentioned in the same breath. However, how does one define culture? The answer is that there is no universal definition for the concept of culture, the Norwegian anthropologist Unni Wikan (2002, p. 80) holds. She points to counts showing that anthropologists had already come up with 156 different definitions of the concept by 1954. The multitude of definitions is also pointed to by the linguist Ingrid Piller who describes culture as "an ideological construct called into play by social actors to produce and reproduce social categories and boundaries" (Piller, 2011, p. 
16). The concept of culture is best portrayed by its complexity. Scollon and Scollon (2001, p. 109) dismiss the concept culture as an explanatory tool, and in terms of cultural practice replace it by the term discourse systems, i.e., human behavior as manifested in the interplay between forms of discourse, face, ${ }^{6}$ ideology, and socialization.

The relationship between linguistic utterances and their context is a recurrent topic in linguistics, and one that has gained ground in the past decades through a dialogical approach to language in which context and interactivity are considered "resources in the meaning-making process" (Linell, 2009, p. 17). This development is due to the recognition that linguistic meaning is intrinsically connected to its context. Before continuing, it is worth noting that the overlap between language and culture is partial in that "certain aspects of language are reasonably considered noncultural [e.g., our articulatory ability], and certain aspects of culture are non-linguistic [e.g., proximity patterns]" (Langacker, 1994, p. 31). In terms of interpreting, our primary interest lies in aspects of the two phenomena that overlap.

The boundary between language, culture, and individual is not an easy one to draw, for more than one reason. The linguist Ronald W. Langacker (1994) describes the relation between language and culture as dependent on language's social nature-a convention or "deal" between the members of a linguistic community:

... the strongest dependency of language on culture is the fact that language is itself a cultural entity, at least to the extent that linguistic structures are conventional and acquired through social interaction. (Langacker, 1994, p. 31)

Langacker (1994, p. 26) simultaneously sees language and culture as partly overlapping with the individual's cognition. However, language and culture are not psychological phenomena, he stresses, because the specific meaning of a linguistic utterance comes into existence in a specific context, as part of a convention that is being constantly renegotiated.

Early definitions of culture frequently emphasized culture as something that was shared and transferred between generations (Piller, 2011; Wikan, 2002). Today most anthropologists agree that culture refers to a sum of knowledge and experiences that have been acquired in a community, and are therefore not innate (Wikan, 2002, p. 80, p. 87). The reason anthropologists stopped enhancing the previously emphasized criterion of "sharedness" is tied to difficulties with determining the size of the community that share a belief, value, or habit:

What would it mean if we said that there must be agreement in a population on knowledge and values for a culture to count as such? The question would logically be: Among how many people? A 
thousand? A hundred? Ten? Two? The question is unanswerable. Rather, as Strauss and Quinn (1994) have argued, "culture" comprises all knowledge and experience embraced by a group or collectivity of people. (Wikan, 2002, p. 80) ${ }^{7}$

A primary problem linked to the concept of culture has to do with the fact that each individual has access to a multitude of cultures, based on generation, gender, profession, region, religion, and other forms of "communities" (Scollon \& Scollon, 2001, p. 3). In our day and time, such multitude even includes virtual reality. This aspect was displayed in the Norwegian media after the terror attacks in Oslo in 2011 (VG, 2 Dec. 2011, pp. 12-15) in a way that serves to illustrate the point made by Scollon and Scollon, as well as the relationship between individual and linguistic convention. In their evaluation of the terrorist's mental state, the first two psychiatrists assigned to the case concluded that the man was psychotic. According to media reports, one of the symptoms on which they based the diagnosis was what they regarded as his extended use of neologisms. What the two renowned psychiatrists did not know, however, was that the concepts they classified as neologisms (e.g., Justicar Knight, National Darwinism) are conventionalized concepts in the virtual world of war games such as Warhammer and World of Warcraft. Hence, the terms he used were conventionalized linguistic currency in communities to which the terrorist was attached, and not his individually coined neologisms. The "nestedness" of culture just illustrated implies that each individual is embedded in a multitude of partly overlapping "communities" or discourse systems, much like the contents of a Russian matryoshka doll (to use a somewhat simplified metaphor). This "nested" nature of the phenomenon 'culture' makes it a poor explanatory tool, be it for the interpreter or the medical professional. In an explanatory function, therefore, "the word 'culture' often brings up more problems than it solves," as stressed by Scollon and Scollon (2001, p. 138).

The next problem with the concept relates to the recognition pointed out by Langacker (1994, p. 26) that all aspects of language and culture are not represented in each individual's cognition; it is simply impossible for the individual to account for all the nuances in a language or culture (as illustrated by the psychiatrists in the terrorist evaluation). Although it must still be assumed that individuals have some sort of cognitive representation of linguistic and cultural units (this is, after all, what enables us to negotiate), we have no guarantee the representations are identical in two individuals (Langacker, 1994, p. 26). The next excerpt from the interpreting students' chat discussion on the Moslem concept mahram, serves to illustrate the lack of a guarantee that our representations are identical, even though we tap into the same linguistic or cultural convention: 
(8) $\quad(\mathrm{m}=$ male, $\mathrm{f}=$ female, Pers $=$ Persian, Sora $=$ Sorani, Viet $=$ Vietnamese, Mand $=$ Mandarin, Fren $=$ French, Urdu $=$ Urdu followed by the time posting)

mSora1-20:28 > it's not only Moslems who wish to have a female doctor, there are many NORWEGIAN women who want a female doctor

fUrdu1-20:29 > A Moslem woman is reluctant to shake hands because it is forbidden to have body contact with other men than those closest to them, something which is difficult to understand for Norwegians.

mPers1-20:29 > How many percent of doctors in all Moslem countries are women?

mSora1-20:31 > There are very few women doctors in the Islamic countries

mSora2-20:31 > if you are really sick you cannot wait to get a woman doctor

mSora3-20:31 > But it's not only doctors they refuse to see, it also concerns the use of male interpreters.

mPers1-20:33 > According to Islam a doctor is mahram.

mViet1-20:34 > What is mahram?

fUrdu1-20:35 > a male doctor cannot be mahram, can he?

mPers2-20:36 > if what mPers1 says is true, then it is not such a big deal whether the doctor is male or female.

fMand1-20:37 > what does the concept Mahram mean?

mSora1-20:40 > Mahram? Many different people can be mahram to a woman, but they feel ashamed to talk about certain things. Hence it has to do with Shame.

mFren1-20:41 > hey, you really have to explain mahram!!!!

fUrdu1-20:41 > a woman's brother, father, husband, and son are Mahram.

mPers1-20:41 > plus doctor.

mSora2-20:42 > Agree with mPers1

The French, Mandarin, and Vietnamese students clearly signal their "nonmembership" in the part of the cultural convention embracing mahram. The students debating the concept's content and ascribing different values to it, all share experiences from a Moslem world (Iran, Iraq, and Pakistan), however. They reveal their differing conceptualizations of mahram despite their common Moslem background. Being an excerpt from a discussion among interpreting students, the example thus serves as a reminder that the interpreter is an individual that does not share all frames of reference with the interlocutors he is serving. This is of course also true with regard to the professional interlocutor, the GP or nurse, who belongs to a professional 
culture with specific terminology that the interpreter may be unfamiliar with. As pointed out by Langacker (1994, p. 31), professional conventions typically illustrate that certain cultural conceptualizations are created and maintained by the linguistic expressions that represent them. If responsibility for explicating terminology in contact with patients does not remain with the medical professional, but is left to the interpreter, miscommunication may arise.

A final problem with the concept of culture is linked to its ability to cover up the fact that "cultures do not meet, individuals do" (cf. Wikan, 2002, p. 83; cf. Scollon \& Scollon, 2001, p. 138). Herein lies the concept's stereotyping force and its link to the phenomenon of 'othering' as defined above. This effect is expressed in the chat posting from the Amharic student in (9). The posting opposes an other student's claim that the interpreter should act as a cultural mediator or advocate, and explains what may be the negative consequences of such an extended interpreter function: the individual as "a wonderful human being" may be lost behind the "exterior" of culture:

(9) $\quad(\mathrm{m}=$ male, Amha $=$ Amharic, followed by the time of posting $)$

mAmha1-19:43 > The individual hiding behind the foreign culture may be a wonderful human being who could make himself understood against all odds, if he or she were given the chance to do so. Here, in my opinion, a good interpretation will reduce prejudice.

Moderator2-19:45 > And how may interpreting help the individual be seen?

mAmha1-19:47 > The professional party in the dialogue will be unable to simply sit and think about the exterior that often contributes to prejudice, but has to listen to the individual in front of him as well. In this situation, the interpreter may contribute to cultural understanding by giving a correct rendition.

In the process of 'othering', minority patients become a large but excluded group of people categorized as non-Norwegians through the constructions of culture. The approach suggested by the student in (9) offers an alternative to 'othering'. The student expresses the idea that the interpreter's function should be restricted to relaying and coordinating the interlocutors' talk in order for the two individuals-doctor and patient-to meet. This is in line with an approach where the interpreter's and the medical professional's areas of expertise are clearly distinguished. Thus, the medical professional is forced to focus on the individual patient and cannot hand over control to the interpreter (Skaaden \& Felberg, 2011). 


\section{Concluding remarks}

This article has illustrated how medical professionals waive their responsibility over institutional dialogue when facing a language barrier. Frequently, this is done by placing the problem source within the patient's culture. When the difference between $U s$ and the Other is recurrently emphasized, potential is created to ascribe the source of a problem to attributes of the Other; thus, 'othering' the minority patient. The construction of "their culture" as the problem source makes it possible to disclaim one's own responsibility for problem-solving. Such a strategy is at odds with medical personnel's area of responsibility as constructed in the legal documents cited in 3.1. The legal documents maintain an understanding of knowledge mediation as an interactive enterprise, but clearly draw a line between the medical professional's and interpreter's areas of responsibility.

Because the medical professionals identify the interpreter as part of the Other, problem-solving is left to this individual as an encyclopedic agent of 'culture'. Our deconstruction of the concept of culture displays this solution's shortcomings. As illustrated, such a strategy may more often conceal than reveal the core problem. Moreover, due to the constant interplay between the individual's cognition, the context and language, the interpreter-an individual-is in essence a problematic mediator of cultures. An alternative construction would be to refrain from using culture as an overall explanatory tool and reframe the assignment of the problem source.

Communication via an interpreter is a complex and challenging endeavor. However, some elements of the communication process can be influenced and controlled in order to lower the risk of misunderstanding. An alternative strategy is to maintain the boundary between the interpreter's and medical professional's areas of expertise. Another strategy would be to address aspects of the medical culture and constructions more explicitly; for example, through explicitness in imparting information and explaining terminology, expectations of patient-therapist relations, parenting, shame and taboos, gender, and so on.

Downplaying "their culture" as the main explanatory tool for perceived barriers in patient-doctor relations will force medical professionals to regain control over institutional discourse and address the individual patient directly. By leaving control with the (sometimes untrained) interpreter, the medical professional stands the risk of malpractice. In the long run, such a strategy may not only be a threat to minority patients' health, but may also jeopardize medical personnel's own professional integrity and status. 


\section{References}

Agar, M. (1985). Institutional discourse. Text, 5(3), 147-168.

Angelelli, C. V. (2004a). Medical interpreting and cross-cultural communication. Cambridge: Cambridge University Press.

Angelelli, C. V. (2004b). Revisiting the interpreter's role. Amsterdam: John Benjamins. Angelelli, C. V. (2008). The role of the interpreter in the healthcare setting, In C. Valero-Garcés \& A. Martin (Eds.), Crossing borders in community interpreting (pp. 147-163). Amsterdam: John Benjamins.

Dahle, M., \& Ryssevik, J. (2011). Tilrettelegging av offentlig informasjon for innvandrere, en studie av policy og praksis i tre sektorer.Report no. 6/2011. Bergen: Ideas2evidence.

Dysart-Gale, D. (2005). Communication models, professionalization, and the work of medical interpreters. Health Communication, 17(1), 91-103.

Felberg, T. R. (in press, a). Much ado about the interpreter's function in the public sector in Norway: Enter the interpreter-user. In ICIFL4, Translation and Interpreting as Intercultural Mediation, Podgorica, Montenegro, University of Montenegro.

Felberg, T. R. (in press, b). Towards a unified model for interpreter user training in communication via interpreter: The Norwegian experience. In PSI publication, University of Leeds.

Felberg, T. R. (2012). Kommunikasjon via tolk for offentlig ansatte, delrapport. [Communication via Interpreters for Employees in the Public Sector]. Unpublished report. Høgskolen i Oslo og Akershus [Oslo and Akershus University College of Applied Sciences].

Felberg, T. R., Imsen, A. W., \& Skaaden, H. (2011). Kommunikasjon via tolk $i$ helsetjenesten. E-læringsmodul. Lørenskog: A-hus.

Finkielkraut, A. ([1984] 1997). The wisdom of love. Lincoln, NB: University of Nebraska Press.

Fox, A., \& Avigad, J. (2007, April). Therapy in translation: Clinical work through an interpreter. Paper presented at Critical Link 5. Sydney.

Galal, L. P., \& Galal, E. (1999). Goddag mand - фkseskaft: Samtale genom tolk. Copenhagen: Mellemfolkeligt Samvirke.

IMDi. (2007). Fastleger og tolketjenester. IMDI-rapport 6-2007. Oslo: Integrerings- og mangfoldsdirektoratet [Directorate of Integration and Diversity].

Jacobs, E. A., et al. (2004). Overcoming language barriers in health care: Costs and benefits. American Journal of Public Health, 94, 866-869.

Jahr, K.,et al. (2005). Rett til tolk: Tolking og oversettelse i norsk straffeprosess. Oslo: Justis- og politidepartementet [Ministry of Justice].

Jareg, K., \& Pettersen; Z. (2006). Tolk og tolkebruker: To sider av samme sak. Oslo: Nasjonal kompetanseenhet for minoritetshelse [ Norwegian Research Center for Minority Health].

KAD. (1997). Retningslinjer for god tolkeskikk. Retrieved from http://www.tolkeportalen.no/Global/tolking/retningslinjer.pdf. 
Kale, E. (2006). 'Vi tar det vi har' Om bruk av tolk $i$ helsevesenet $i$ Oslo. NAKMIs skriftserie om minoriteter og helse. Oslo: NAKMI. 2/2006.

Kale, E., Ahlberg N., \& Duckert, H. (2010). Hvordan håndterer helsepersonell språklige barrierer?: En unders $\varnothing$ kelse av tolkebruk i helsevesenet. Tidsskrift for Norsk Psykologforening, 47(9), 818-823.

Langacker, R. W. (1994). Culture, cognition, and grammar. In M. Pütz. (Ed.), Language contact and language conflict (pp. 25-55). Amsterdam: John Benjamins.

Linell, P. (2009). Rethinking language, mind, and world dialogically: Interactional and contextual theories of human sense-making. Charlotte, NC: Information Age.

Maccallum, E. J. (2002). Othering and psychiatric nursing. Journal of Psychiatric and Mental Health Nursing, 9, 87-94.

Merlini, R. (2009). Interpreters in emergency wards: An empirical study of doctorinterpreter-patient interaction. In R. De Pedro Ricoy, S. Perez, \& C. W. L. Wilson. (Eds.), Interpreting and translating in public service settings: Policy, practice, pedagogy (pp. 89-115). Manchester: St Jerome.

Meyer, B. (2001). How untrained interpreters handle medical terms. In I. Mason (Ed.), Triadic exchanges: Studies in dialogue interpreting (pp. 87-107). Manchester: St Jerome.

Mikkelson, H. (1996). Community interpreting: An emerging profession. Interpreting, $1(1), 125-129$.

Piller, I. (2011). Intercultural communication: A critical introduction. Edinburgh: Edinburgh University Press.

Potter, J. (1996). Representing reality: Discourse, rhetoric and social construction. London: Sage.

Pöchhacker, F. (1997). Kommunikation mit Nichtdeutschsprachigen in Wiener Gesundheits- und Sozialeinrichtungen (Part 2). Vienna: Gesundheitswesen der Stadt Wien.

Pöchhacker, F. (2004). Introducing interpreting studies. London: Routledge.

Pöchhacker, F. (2008). Interpreting as mediation. In C. Valero-Garcés \& A. Martin (Eds), Crossing borders in community interpreting: Definitions and dilemmas (pp. 9-27). Amsterdam: John Benjamins.

Rudvin, M. (2006). Negotiating linguistic and cultural identities in interpreter-mediated communication for public health services. In A. Pym, M. Shlesinger, \& Z. Jettmarová (Eds.), Sociocultural aspects of translating and interpreting (pp. 173-190). Amsterdam: John Benjamins.

Rudvin, M., \& Tomassini, E. (2008). Migration, ideology and the interpreter-mediator: The role of the language mediator in educational and medical settings in Italy. In C. Valero-Garcés \& A. Martin (Eds), Crossing borders in community interpreting: Definitions and dilemmas (pp. 245-267). Amsterdam: John Benjamins.

Scollon, R., \& Scollon, S. B. K. (2001). Intercultural communication: A discourse approach. Malden, MA: Blackwell.

Skaaden, H. (2003). On the bilingual screening of interpreter applicants. In Á. ColladosAís, M. M. F. Sánchez, \& D. Gile (Eds.), La evaluación de la calidad en interpretación: Investigación (pp. 73-85). Granada: Interlingua. 
Skaaden, H. (2007, April). Public sector interpreting: A case for the constitutional state. Paper presented at Critical Link 5. Sydney.

Skaaden, H. (2010). Tolken: Håndverker eller tusenkunstner? In S. Dillevig et al.(Eds.), Nettopp norsk. Bok og nett $i$ ett. Studieforberedende utdanningsprogram (pp. 470-473). Oslo: Aschehoug.

Skaaden, H., Felberg, T. R. (2011). Språkbarrierer og profesjonell integritet i psykologers virke [ Language barriers and professional integrity in psychologists' practice]. Tidskrift for Norsk Psykologforening, 48, 535-537.

Skaaden, H., \& Wattne, M. (2009). Teaching interpreting in cyber-space: The answer to all our prayers? In R. De Pedro Ricoy, A. Perez, \& C. W. L. Wilson (Eds.), Interpreting and translating in public service settings: Policy, practice, pedagogy (pp. 74-89). Manchester: St Jerome.

Valero-Garcés, C., \& Martin, A. (2008). Crossing borders in community interpreting: Definitions and dilemmas. Amsterdam: John Benjamins.

Wadensjö, C. (1998). Kontakt genom tolk. Stockholm: Dialogos.

Wikan, U. (2002). Generous betrayal: Politics of culture in the new Europe. Chicago: University of Chicago Press.

Woloshin, S. et al. (1995). Language barriers in medicine in the United States. JAMA, 273(9), 724-728.

1 The survey directed at fastleger (i.e., GPs with appointed patients) was carried out by IMDi in cooperation with the research organization Synovate MMI and the Norwegian Directorate of Health. The aim was to map the availability of interpreting services, as well as the GPs' attitudes and routines when facing language barriers. The questionnaire was compiled by Hanne Skaaden in cooperation with coworkers at IMDi and Håkon Kavli of Synovate MMI. The statistical analysis was handled by Synovate MMI. Norway's 3,872 GPs were mailed via channels of The Norwegian Directorate of Health and offered NOK 500 to respond. The response rate was $42 \%(n=1,596)$, thus, statistically representative for the population of GPs as a whole.

2 There is a growing body of literature on the interpreter's role in the medical setting in particular (e.g., Angelelli 2004b, 2008, Valero-Garcés and Martin 2008). Here we do not engage in this line of discussion, however. From our vantage point, the medical setting is part of the wider public sector setting (see Mikkelson, 1996, p. 126), and we define the interpreter's function in the public sector setting accordingly (see above and Jahr et al., 2005, Skaaden, 2003, 2007). For discussions of an expanded interpreter function, see for example Angelelli, 2004a; Fox and Avigad, 2007; Galal and Galal, 1999; Jareg and Pettersen, 2006; Pöchhacker, 2008; Rudvin \& Tomassini, 2008. 
3 The program will be freely available at www.tolkeportalen.no at the end of 2012.

4 See the Health Personnel Act (Lov om helsepersonell) and the Specialist Health Services Act (Lov om spesialisthelsetjenester) at www.lovdata.no.

5 The excerpts from the chat discussions are translated from Norwegian, and the translations mirror that Norwegian is the students' L2.

6 The concept face is widely employed in sociolinguistics and discourse analysis, as defined by Scollon and Scollon (2001, p. 45) in the following way: "Face is the negotiated public image, mutually granted each other by participants in a communicative event."

7 This definition is much in line with that of the philosopher Alain Finkielkraut (1997, p. xv): culture, according to him, "consists of that which expresses the life of a people, group or collectivity, but which escapes the limits of collective being." 